\title{
The role of adolescents' morality and identity in volunteering. Age and gender differences in a process model
}

\author{
Anne A.J. van Goethem*, Anne van Hoof, Marcel A.G. van Aken, Quinten A.W. Raaijmakers, \\ Jan Boom, Bram Orobio de Castro
}

Department of Developmental Psychology, Utrecht University, Heidelberglaan 1, P.O. Box 80140, 3508 TC Utrecht, The Netherlands

\section{Keywords:}

Volunteering

Morality

Identity

Gender

Age

Adolescents

\begin{abstract}
A B S T R A C T
The aim of this study was to explain adolescents' volunteering in terms of their morality and identity and to examine the moderation effect of gender and age in this process. Data were collected among 698 Dutch adolescents aged 12 to $20(M=15.19 ; S D=1.43)$. Adolescents' moral reasoning was positively associated with understanding moral issues and thinking about public responsibility towards these issues. In turn, moral understanding, along with being personally committed to act upon moral issues, were positively associated with identity. Extending the number of identity contexts tended to be related to being more likely to volunteer and to more volunteering involvement. Adolescents' identity integration was not related to how likely they were to volunteer, and was negatively related to their volunteering involvement. Clearer effects were found when differentiating between adolescent gender and age groups. Future research could examine this process over time, along with additional factors that may further explain adolescents' volunteering, and examine their age and gender specific effects.
\end{abstract}

(C) 2011 The Foundation for Professionals in Services for Adolescents. Published by Elsevier Ltd. All rights reserved.

\section{Introduction}

In contrast to the common view that adolescents are increasingly disengaged from society and civic issues (e.g., Bennett, 2000; Cook, 2004; Harris, Wyn, \& Younes, 2010), recent studies suggest that many adolescents do try to contribute to society. The ways by which they do this, however, have developed from mainly traditional forms, such as being a member of a political party or voting for elections (e.g., Zukin, Keeter, Andolina, Jenkins, \& Delli Carpini, 2006), to also newer forms of engagement, such as signing petitions, demonstrating, boycotting products, and expressing one's opinions through new media such as interactive websites (e.g., Coleman \& Rowe, 2005; Flanagan, Levine, \& Settersten, 2009).

Adolescent engagement is a topic of major public interest as it not only contributes to society, but also positively stimulates adolescents' own development. It promotes, for example, adolescents' life-satisfaction, self-rated health, self-esteem, educational and occupational achievement, sense of agency, social relatedness, and their moral-political awareness (e.g., Youniss \& Yates, 1999; Wilson, 2000). As adolescent engagement is considered important and is stimulated by the government, schools and educators, it is important to gain more insight into the factors associated with adolescent engagement. Knowledge about these factors may provide tools to current initiatives stimulating adolescent engagement.

\footnotetext{
* Corresponding author. Tel.: +31 30 2534289; fax: +31 302534718.

E-mail address: A.A.J.vanGoethem@uu.nl (A.A.J. van Goethem).
} 
In the current study we aim to explain adolescents' engagement, more particular various (traditional and new) forms of volunteering, by adolescents' morality and identity. Morality and identity are important, relatively stable predictors of concurrent and future volunteering (e.g., Grube \& Piliavin, 2000; Matsuba, Hart, \& Atkins, 2007; McLellan \& Youniss, 2003).

Although some theorists have described how morality and identity together can influence volunteering behaviour (for an overview see Bergman, 2002), earlier empirical research has mainly focused on the relation between volunteering and morality or identity independently, and has paid less attention to the interrelations between different aspects of morality and identity (e.g., Hardy, 2006; Matsuba et al., 2007; Pitt \& Thoma, 2005). In the current study we will therefore focus on the processes by which different aspects of adolescents' morality and identity together explain adolescent volunteering behaviour. As age and gender differences have often been found for volunteering (e.g., Fabes, Carlo, Kupanoff, \& Laible, 1999; Karniol, Grosz, \& Schorr, 2003; Matsuba et al., 2007; Metz \& Youniss, 2003; Wilson, 2000), we will also study the effects of age and gender on these processes.

\section{Moral reasoning, moral thought and volunteering}

Over the last decades, research on the relation between morality and volunteering behaviour has mainly emphasized the role of moral reasoning (Kohlberg \& Candee, 1984; Walker, 2004). Moral reasoning can be defined as "a psychological construct that characterizes the process by which people determine that one course of action in a particular situation is morally right and another course of action is wrong" (Rest, Thoma, \& Edwards, 1997). Moral reasoning is distinguished from other forms of reasoning, such as conventional reasoning (reasoning on relatively arbitrary rules and regulations that structure social interactions in social systems), as it concerns issues that inherently have consequence for other's welfare and rights (Yau \& Smetana, 2003; Nucci, 1996). Kohlbergian theorists argue that moral reasoning as an inner psychological process, can give rise to outwardly observable behaviour, such as volunteering (Rest, Narvaez, Bebeau, \& Thoma, 1999). They argue that a higher level of moral reasoning leads to a stronger motivation to act accordingly to one's moral principles. Next to that it has been shown that volunteering can be experienced as a moral act as it directly affects the welfare of others (Metzger \& Smetana, 2009). We therefore hypothesized that a higher level of moral reasoning could also be related to (being) more (inclined to show) volunteering behaviour (e.g., Eisenberg, Carlo, Murphy, \& Van Court, 1995; Kohlberg \& Candee, 1984). However, overall, only small to moderate relations have been found between moral reasoning and prosocial behaviours such as volunteering (e.g., Eisenberg, 1982; Eisenberg et al., 1995; Hardy, 2006).

Moral reasoning refers to the level of reasoning given a hypothetical moral dilemma concerning abstract categories (such as justice, duty, and rights; Narvaez, Getz, Rest, \& Thoma, 1999). It may therefore not show direct, strong associations with specific real life (moral) behaviour such as volunteering (cf. Higgins-D'Alessandro, 2008; Boom \& Brugman, 2005). Moral theorists and researchers therefore argue that additional concepts are also important in volunteering (e.g., moral motivation; Rest, Bebeau et al., 1999) or that intermediate (moral) concepts concerning actual issues instead of hypothetical dilemma's are more close to - and therefore more important for - adolescents' volunteering (e.g., Blasi, 1983, 1995; Narvaez et al., 1999).

One of these intermediate concepts is general moral thought (i.e. a body of thought) which represents thinking about and being committed to defend adolescent, moral rights issues (cf. Rest, Bebeau et al., 1999), as for example defined in the Convention on the Rights of the Child (http://www.2ohchr.org/english/law/crc.htm; Narvaez et al., 1999; Raaijmakers \& van Hoof, 2006).

Where moral reasoning refers to the level or stages of reasoning on hypothetical moral dilemmas about individual values (e.g., life and punishment; Colby et al., 1987), general moral thought refers to a broad spectrum of high level, issues on actual, internationally defined moral rights (civil, social, economic, political, and cultural rights; Boulware-Miller, 1985). As the focus of these moral rights issues is on children and adolescents, they actually affect adolescents' lives. From this perspective, they are less abstract and distant from adolescents' lives than Kohlbergian moral reasoning and therefore are possibly also more close to actual (volunteering) behaviour.

In addition, in contrast to moral reasoning, general moral thought consists of not only two cognitive elements but also one motivational element. Moral understanding and moral referral are cognitive elements. Moral understanding is the extent to which one understands the content of moral rights issues, as well as agrees with these issues (having an understanding for these issues). Moral referral is the extent to which one is able to understand collective moral responsibility: How the public, the government or people in general, are responsible for the defence and continuation of moral rights issues (cf. Helwig, 1998; Rest, Bebeau et al., 1999; Raaijmakers \& van Hoof, 2006).

Moral commitment represents the motivational element of general moral thought. It refers to the extent to which one feels personally responsible for and committed to moral rights issues (cf. Blasi, 1983, 1995; moral motivation, Rest, Bebeau et al., 1999; Raaijmakers \& van Hoof, 2006). The fact that general moral thought contains both a cognitive as well as a motivational element, the latter being an important predictor of actual behaviour (Chapman \& Morley, 1999; Clary et al., 1998), may be an additional reason to expect that general moral thought is more close to volunteering than moral reasoning.

Research has shown that general moral thought is distinct from, but related to moral reasoning: Moral reasoning is positively related to the two cognitive elements of general moral thought (Derryberry \& Thoma; 2005; Narvaez et al., 1999; Pitt \& Thoma, 2005; Raaijmakers \& van Hoof, 2006; Rest, Bebeau et al., 1999). General moral thought has shown to be an important predictor of engagement such as volunteering, especially in adolescence. In this period considering the needs of others becomes an increasingly important motive for social behaviour and volunteering (e.g., Lies \& Bock, 2008; Matsuba et al., 2007; Omoto \& Snyder, 2002). We therefore hypothesize that the three components of general moral thought are 
important intermediate concepts in the process leading from moral reasoning to volunteering behaviour: We expect that moral reasoning is positively related to the cognitive elements of general moral thought (i.e., moral understanding and moral referral) and that general moral thought, consisting of moral understanding, moral referral, and moral commitment, in turn is associated with volunteering.

\section{Identity and volunteering}

Research on identity and volunteering in adolescence has mainly focused on volunteering as becoming part of and relating oneself with society. Adolescents participate in different societal contexts in which they can explore different roles, values and ideologies, which can contribute to becoming healthy members of society. Most adolescents participate in the contexts of school, home and leisure. Others choose to participate in yet other contexts, such as volunteering (cf. Dornbusch, Herman, \& Morley, 1996; van Hoof \& Raaijmakers, 2002). Adolescents differ in the number of identity contexts in which they participate, but they also differ in the extent to which they consider each of these contexts to be important for their sense of identity (Kroger, 1988; van Hoof, 1999).

Due to their participation in different societal contexts, adolescents develop a sense of self within each of these contexts (Erikson, 1968; Yates \& Youniss, 1998; Youniss \& Yates, 1999). However, adolescents not only develop context-specific identities but also integrate these different context-specific identities into an idea of being the same person over different contexts and over time: a sense of temporal-spatial continuity (Côté \& Levine, 2002; Erikson, 1968; Kroger, 1993). This sense of temporal-spatial continuity, or identity integration, is an essential characteristic of adolescent identity development (Côté \& Levine, 2002; van Hoof, 1999; van Hoof \& Raaijmakers, 2002).

The importance of a solid identity integration has been demonstrated: Adolescents who are better at integrating their context-specific identities, report a stronger sense of well-being (van Hoof \& Raaijmakers, 2002). In addition, an integrated identity forms a solid basis for an extension of one's identity horizon: Research suggests that adolescents tend to participate in identity contexts outside their direct environment, (which are most often constructed by school, home, and leisure as identity contexts, van Hoof \& Raaijmakers, 2002) when their identity integration is solid (van Hoof, 1997; van Hoof \& Raaijmakers, 2002).

Adolescents' identity integration and their number of identity contexts are expected to be positively associated with each other: Adolescents who have a stronger identity integration are expected to be more likely to explore and extend their identity with contexts such as volunteering behaviour (van Hoof, 1997; van Hoof \& Raaijmakers, 2002). In the current study we will examine whether a more solid identity integration and having a larger number of personally important identity contexts are related to being more likely to volunteer.

The relationship between adolescents' volunteering, morality, and identity

In previous research, the relations of morality and identity with volunteering have been mainly studied separately (e.g., Hardy, 2006; Matsuba et al., 2007; Pitt \& Thoma, 2005). We however expect that different aspects of identity and of morality together can lead to adolescents' volunteering. We expect that a higher level of adolescents' moral reasoning may lead to further developed general moral thought, which involves both cognitively understanding real life moral issues (moral understanding) and considering what others can do about these issues (moral referral). In turn, this moral understanding and moral referral could make that adolescents see more opportunities for moral behaviour such as volunteering.

Some theorists as well as previous empirical research, however, suggest that general moral thought would not directly lead to volunteering, but would lead to volunteering through the process of affecting or changing adolescents' identity (cf. Bergman, 2002; Blasi, 1983, 1995; Erikson, 1968; Hardy, 2006; Jennings, 1996; Youniss \& Yates, 1999). Adolescents' moral understanding and moral referral could lead to stronger identity integration by stimulating adolescents' reflection on rules that structure the context-specific identities into a whole: the more structuring rules are applied, the more solid is the integration (van Hoof \& Raaijmakers, 2003; cf. Erikson, 1968; Jennings, 1996). These rules could be mainly moral (placing context-specific identities into a wider societal and moral perspective; cf. Jennings, 1996) or mainly cognitive in nature (cf. Helwig, 1998; cognitive abstraction or organizational rules can help to further integrate one's identity, e.g., van Hoof \& Raaijmakers, 2003).

More solid identity integration, in turn, forms a solid basis for choosing new ways to participate in society, such as choosing to volunteer. Next to that, adolescents' reflection on their responsibility and commitment to act upon these moral issues is likely to broaden adolescents' identity horizon to societal contexts which can involve volunteering (e.g., van Hoof \& Raaijmakers, 2002).

We therefore hypothesize that adolescents' moral understanding and moral referral is related to volunteering by affecting their identity integration, and that adolescents' moral commitment is related to volunteering via the number of their personally relevant identity contexts.

The effects of age and gender in the process model

Age has often been found to be associated with volunteering (e.g., Fabes et al., 1999; Matsuba et al., 2007; Metz \& Youniss, 2003; Wilson, 2000), moral reasoning (e.g., Eisenberg, Cumberland, Guthrie, Murphy, \& Shepard, 2005; Rest, 1979), general 
moral thought (cf. Helwig, 1998; Torney-Purta, 1991), identity integration, and the number of chosen identity contexts (e.g., van Hoof \& Raaijmakers, 2002). If the model is able to describe the process of volunteering, then the process factors could partly mediate the relation between age and volunteering. Less is known on whether and how the interrelations between these variables would differ between adolescent age-groups. We therefore also analyzed our model for younger (12-15 years old) versus older adolescents (16-20 years old).

Some studies suggest that girls are more involved in volunteering than boys (e.g., Karniol et al., 2003; Wilson, 2000). Compared to this mean gender difference, less is known on whether and how boys and girls would differ on their interrelations between morality, identity, and volunteering. We therefore also tested our model for differences between boys and girls.

\section{Method}

Participants and procedure

Data for our study came from 698 adolescents. Participants (47.7\% male, 52.3\% female) were between 12 and $20(M=15.19$; $S D=1.43$ ) years old, and came from eight higher general education and pre-university education high schools. $83.9 \%$ of the participants were of Dutch origin, and 16.1\% were first or second generation immigrants: $8 \%$ were Western immigrants and $8 \%$ were non Western immigrants. In addition, $58.7 \%$ were non religious whereas $41.3 \%$ indicated to be a member of church or religious community. Religious adolescents indicated to be Catholic (24\%), Protestant-Christian (10.2\%), Islamic (4.3\%), Hindu ( $0.9 \%)$, or of another religious background (1.9\%). Most adolescents came from two-parent households (82.1\%) and most adolescents had one or more siblings (90.4\%). Lastly, 33\% of the adolescents indicated to have performed volunteering in the past year, which is in the range of volunteering ratings in Dutch society (MOVISIE, 2011).

Schools were approached and asked to participate in our study. After permission was obtained, schools were given information letters for the parents of the adolescents. In accordance with local ethical guidelines, passive consent was provided by all participants. In each school class, data were collected with a digital questionnaire (Netquestionnaires, www. netq.nl) in two separate sessions of one school-hour (45-50 min). Each hour started with one or two trained examiner(s) personally assigning adolescents to the computers in the classroom to prevent friends from sitting next to each other. Participants were given a brief, standardized introduction and instruction. In this instruction adolescents were guaranteed confidentiality and were asked to answer all items of the questionnaire individually, without talking to their classmates.

\section{Measures}

\section{Volunteering}

We used the Civic Prosocial Behavior Inventory (CPBI, van Goethem, 2009; available upon request from the first author), an adaption and combination of existing volunteering questionnaires (Andolina, Keeter, Zukin, \& Jenkins, 2003; Bekkers \& Boezeman, 2009; Carlo \& Randall, 2002; Gaskin \& Smith, 1997; Low, Butt, Ellis Paine, \& Davis Smith, 2007; Youniss, Yates, \& Sue, 1997). The CPBI (van Goethem, 2009) was used to assess whether adolescents volunteer. Among the adolescents who indicated to volunteer we also assessed: a) their volunteering involvement, b) the kind of volunteering organization they are involved in, c) their volunteering motivations, and d) adolescents' evaluation of their volunteering.

In the current study we only focused on that part of the CPBI (van Goethem, 2009) that assesses whether adolescents volunteered and adolescents' volunteering involvement. Adolescents indicated whether they had ever volunteered in an organization during the past year (yes $=1$, no $=0 ; N=232$ and $N=466$, respectively). Organized volunteering work was defined as: activities within an organization, society, or club, which is intended to positively contribute to the environment, individuals, groups of people, or the society as a whole, without receiving money (small compensations are allowed). Adolescents who indicated to volunteer, were also presented with a set of twenty-two traditional as well as new forms of volunteering activities, such as organizing an event, collecting money, domestic work, signing petitions, demonstrating, boycotting products, or administering the website of an organization. They reported whether, and if so, how often they had performed each of these activities for the organization they had been most active in on a scale that ranged from one to seven ( 1 = 'not', 2 = 'not, but maybe in the future', 3 = 'among one to four times', 4 = 'among five to ten times', $5=$ 'among once a month', 6 = 'among once a week', 7 = 'among several times a week'). If participants indicated that they were active in a second organisation, they answered the same questions again for that organisation. Adolescents' volunteering involvement score was calculated by recoding 'not', and 'not, but maybe in the future' into no involvement $(=0)$ and the other amounts of involvement from 1 to $5(3=1,4=2,5=3,6=4,7=5)$. All separate activity scores for maximally two organizations were summed and then divided through the number of volunteering activities assessed (22) resulting in an average volunteering involvement score that could range from zero to five; with a higher score indicating a larger amount of time spent to volunteering work. In our sample, participants' mean score was $.11(S D=0.25)$, with a minimum score of 0 and a maximum score of 2 .

\section{Moral reasoning}

A Dutch translation of the short version of the Defining Issues Test (DIT; Rest, 1979) was used to assess the level of adolescents' moral reasoning. The DIT is regarded a valid and reliable measure of moral judgement (Thoma, 2002). The short 
version consists of three moral dilemmas. Adolescents were asked to read a dilemma and were asked what the main character should do. For each dilemma, adolescents were asked to rate and rank 10 statements in terms of importance in making their decision on the dilemma on a 5 -point Likert scale $(1=$ unimportant to $5=$ very important). Each of these statements is indicative of one of five stages of moral reasoning (stages 2-6; Kohlberg, 1969; Rest, 1979). Adolescents' answers were then used to calculate an N2 index score (for a detailed description of the computing procedure of the N2 index see Rest, Thoma, Narvaez, \& Bebeau, 1997). This score represents the degree to which adolescents use postconventional moral reasoning (stage 5 and 6) compared to preconventional moral reasoning (stage 2 and 3), with a higher score indicating a higher level of moral reasoning. In the present study, Cronbach's alpha was 0.81 .

\section{General moral thought}

The Children's Rights Evaluation Questionnaire (CREQ; van Hoof \& Raaijmakers, 2010) was used to assess adolescents' general moral thought. We used five articles of the Convention on the Rights of the Child (http://www2.ohchr.org/english/ law/crc.htm) representing the different categories of rights: civil, social, economic, political, and cultural rights (BoulwareMiller, 1985), and provision, protection, and participation rights (Lansdown, 1995). These articles were described in comprehensible language for adolescents. Article 14, for example, was described as: 'Each child has the right to freedom of thought, conscience and religion, taking into account the responsibility of parents and the laws of the countries.'

Adolescents were asked to evaluate each of the five articles by scoring each article on eight 9-point scales: (1) difficulteasy to understand, (2) difficult-easy for governments to apply, (3) does-does not make people responsible for each other (reversed scale), (4) political parties can-cannot do much to enforce this article (reversed scale), (5) it is-it is not about me, as a person (reversed scale), (6) I can do a great deal-very little for this article to be respected/observed (reversed scale), (7) I don't agree-I agree with every aspect of this article, and (8) I am-I am not, together with others, willing to make an effort to defend this article (reversed scale; cf. Doise, Spini, Jesuino, Ng, \& Emler, 1994; Raaijmakers \& van Hoof, 2006).

Factor analysis showed that these eight questions represented three factors: (1) moral understanding: $\alpha=0.88$ (question 1 and 7); (2) moral referral: $\alpha=0.75$ (question 2, 3 and 4); (3) moral commitment: $\alpha=0.87$ (question 5,6 , and 8 ). These factors were transformed to three corresponding, latent variables in our model. Due to the large number of questions (10-15 questions for each factor), we randomly assigned these questions to one of three parcels for each of the latent factors, with each parcel containing among an equal number of items (Little, Cunningham, Shahar, \& Widaman, 2002). The factor loadings of these parcels ranged from 0.67 to 0.87 and this latent factor solution fitted the data satisfactorily (CFI $=.97$, RMSEA $=0.08$ ).

\section{Personal identity: identity contexts and identity integration}

Adolescents' identity was measured with the Spatial Continuity of Identity Questionnaire (SCIQ; van Hoof \& Raaijmakers, 2002), which has shown to be a valid measure of identity. First, adolescents were asked to evaluate 20 items, representing four identity dimensions which are often explicitly or implicitly measured in former identity status research (see also van Hoof, 1997): Competence (four items referring to individual abilities, e.g. "I make a decision easily"), Inhibition (six items representing self-doubt that has a paralyzing effect, e.g. "I am insecure"), Feeling (four items, e.g. "I am lonely"), and Interpersonal Behavior (six items representing how individuals relate to, or act towards, their social environment, e.g. "I am bossy"). These items were evaluated on a seven-point scale ranging from "I am totally not like that" to "I am totally like that'. Second, the number and content of adolescents' context-specific identity were assessed. The number of adolescents' identity contexts was assessed by providing adolescents with seven identity contexts, from which they could choose all their personally revealing identity contexts. These seven contexts, adjusted to the adolescent way of life (and often used as identity contexts in former identity research; van Hoof, 1997), were: school, home, own home (defined as living independently from the parents), leisure time, work, religion, and politics (defined as being active in for instance Amnesty International or in a students' board). Then the content of their context-specific identities was assessed by asking them to evaluate the same 20 items for each of their three most personally revealing identity contexts. Each adolescent's identity integration was determined by calculating the correlations between each adolescent's general description of identity and each of their three context-specific identities. The mean of these correlations represents their level of identity integration, with a higher score representing a more integrated identity. ${ }^{1}$

\section{Analyses}

The hypothesized relations between age, moral reasoning, moral development, identity and volunteering of our process model were studied with Structural equation modelling (SEM) using Mplus (Version 6; Muthén \& Muthén, 1998-2010). We used zero inflated poisson regression to account for the large number of zero-scores (non-volunteers) in our volunteering measure by combining a point mass at zero with a proper count distribution (for a detailed description of zero inflated

\footnotetext{
${ }^{1}$ Referred to as 'vertical identity integration' in the article of van Hoof and Raaijmakers (2002). In the latter article, vertical identity integration is distinguished from 'horizontal identity integration', which is an alternative method to determine identity integration (horizontal identity integration is the average of the correlation between adolescents' context-specific identities), but they are highly related concepts (in our study: $r=0.82, p<0.01$ ). As participants did not consciously relate their context specific identity-descriptions to their general identity-description, our measure of identity integration differs from related concepts such as self-unity and self-continuity (e.g., Proulx \& Chandler, 2009), that (mainly) rely on conscious self-reports of identity integration.
} 
poisson regression see Lambert, 1992). It combines predicting the inflated binary volunteering variable (not volunteering $=0$ and volunteering $=1$ ) with a regression predicting the value of the count dependent variable (the involvement in volunteering for adolescents who volunteered). To prevent problems of non-convergence due to divergent values of variances, we divided participants' moral reasoning scores by 100 before using them in our analyses. The percentages of missing data for the variables in our model varied between 1\% (age) to $16.3 \%$ (general moral thought). Monte Carlo integration with robust maximum likelihood estimation (MLR) was used to estimate missing data, and to calculate the bias-corrected standard errors and confidence interval (Muthén \& Muthén, 1998-2010). For the calculation of the correlations between the variables in our model, we used the average scores on each of the three factors of general moral thought. For the remaining analyses we used these factors as latent variables.

Multi-group analyses within Mplus were used to analyze the moderation effect of age and gender. Improvement in model fit was tested with the Satorra-Bentler $\Delta \mathrm{X}^{2}$-difference test (Satorra \& Bentler, 2001). Indirect effects were calculated using Aroian's version of the Sobel test (Muthen \& Muthen, 1998-2010). Initially, we also controlled for adolescents' cultural origin (belonging to an ethnic minority or not) and religion in our model. However, as neither cultural origin nor religion changed the estimates of the model, we did not include these control variables in our final model for reasons of parsimony.

\section{Preliminary results}

Means and correlations between the variables of our process model are presented in Table 1. Adolescents' age was related to all variables except for moral commitment and identity integration. Moral reasoning was related to the two cognitive elements of general moral thought (moral referral and moral understanding) and to identity integration. In turn, these two aspects of adolescents' general moral thought were positively related to each other and to identity integration. Adolescents' moral commitment was positively related to moral referral and the number of their identity contexts. In turn, moral understanding and the number of identity contexts were positively related to whether adolescents volunteered. The number of identity contexts was also positively related to adolescents' identity integration and to their volunteering involvement. Lastly, adolescents' identity integration was negatively related to their volunteering involvement and was not related to whether adolescents volunteered.

\section{Results}

The estimated model is depicted in Fig. 1. The relative model fit was: InL: - 12221. 59 (number of freely estimated parameters $=53 ; \mathrm{c}=2.17$ ). With increasing age, adolescents were more likely to volunteer, but, if they did, were not more involved in volunteering work. As expected, age was also positively related to the level of moral reasoning, which in turn was positively related to the cognitive elements of general moral thought (moral understanding and moral referral). Two of the three factors of general moral thought were positively related to one another: Moral referral was positively related to moral commitment $(r=.49 ; p<.01)$, and to moral understanding $(r=.48 ; p<.01)$, but moral commitment was not related to moral understanding $(r=-.07, p=.26)$. Also, two of three elements of general moral thought were related to adolescents' identity: A higher level of moral understanding was related to a further integrated identity, and a higher level of moral commitment was related to higher number of personally relevant identity contexts. However, adolescents' moral referral was unrelated to their identity integration. The two aspects of adolescents' identity were positively related to each other $(r=0.18 ; p<0.01)$. We also found a marginally significant, positive association between adolescents' identity contexts and volunteering: A higher number

Table 1

Means and correlations between the variables within the process model.

\begin{tabular}{|c|c|c|c|c|c|c|c|c|c|c|c|c|c|}
\hline & \multirow[t]{3}{*}{1} & \multirow[t]{3}{*}{2} & \multirow[t]{3}{*}{3} & \multirow[t]{3}{*}{4} & \multirow[t]{3}{*}{5} & \multirow[t]{3}{*}{6} & \multirow[t]{3}{*}{7} & \multirow[t]{3}{*}{8} & \multicolumn{5}{|c|}{ Volunteering } \\
\hline & & & & & & & & & \multicolumn{2}{|l|}{0} & \multicolumn{2}{|l|}{1} & \multirow[t]{2}{*}{ pdiff } \\
\hline & & & & & & & & & $M$ & $S D$ & $M$ & $S D$ & \\
\hline 1. Age & & & & & & & & & 15.03 & 1.38 & 15.50 & 1.43 & $<0.01$ \\
\hline 2. Moral reasoning & $0.18^{* *}$ & & & & & & & & 2.45 & 1.42 & 2.58 & 1.49 & 0.26 \\
\hline 3. Moral commitment & 0.06 & 0.04 & & & & & & & 4.93 & 1.39 & 4.98 & 1.16 & 0.67 \\
\hline 4. Moral referral & $0.11^{* *}$ & $0.15^{* *}$ & $0.48^{* *}$ & & & & & & 5.69 & 1.41 & 5.76 & 1.48 & 0.60 \\
\hline 5. Moral understanding & $0.19 * *$ & $0.17 * *$ & -.04 & $0.20 * *$ & & & & & 6.27 & 1.35 & 6.57 & $1.35^{*}$ & $<0.05$ \\
\hline 6. Identity contexts & $0.13^{* *}$ & -0.02 & $0.11^{* *}$ & 0.06 & 0.01 & & & & 2.83 & 1.10 & 3.04 & $1.13^{*}$ & $<0.05$ \\
\hline 7. Identity integration & 0.00 & $0.13 * *$ & 0.05 & $0.13^{* *}$ & $0.32 * *$ & $0.17^{* *}$ & & & 0.69 & 0.23 & 0.69 & 0.24 & 0.63 \\
\hline 8. Volunteering involvement & $0.12^{* *}$ & 0.01 & 0.02 & -0.02 & -0.05 & $0.09^{*}$ & $-0.10^{*}$ & & & & & & \\
\hline$M$ & 15.19 & 2.49 & 4.95 & 5.71 & 6.38 & 2.91 & 0.69 & 0.11 & & & & & \\
\hline$S D$ & 1.43 & 1.43 & 1.31 & 1.43 & 1.35 & 1.12 & 0.23 & 0.25 & & & & & \\
\hline
\end{tabular}

Note. For the dichotomous aspect of volunteering in our model, the average scores on the variables in our model for adolescents who did not volunteer ( 0 ) and for adolescents who volunteered (1) are presented; pdiff= significance of the difference between the mean scores for adolescents who did not volunteer (0) and who volunteered (1). For those adolescents who volunteered (1), correlations between volunteering involvement and the other variables within our model are also presented.

$*^{* *} p<.01 ; * p<.05$. 


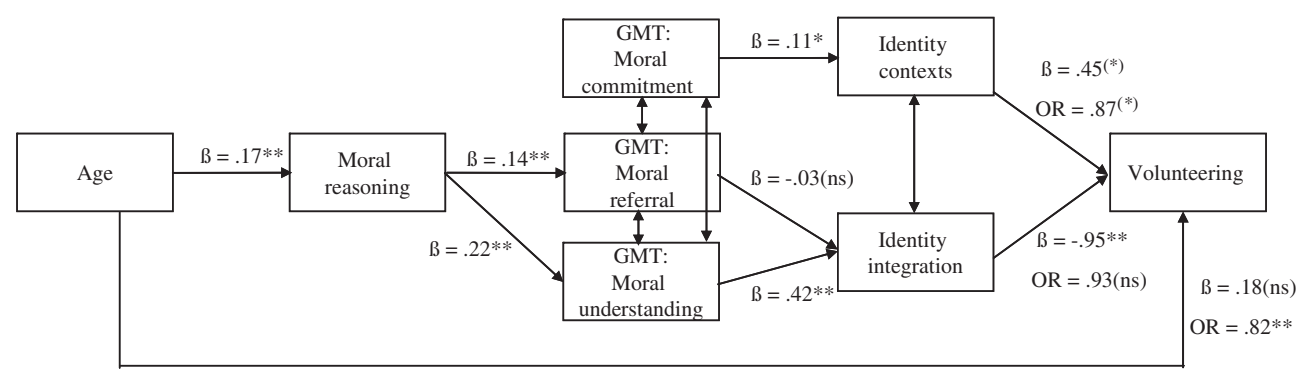

Fig. 1. Parameter estimates ( $\beta$ 's) for the variables within the process model: of age, moral reasoning, general moral thought (GMT), and identity to volunteering. For the paths from identity to volunteering, the first value is the parameter estimate for volunteering involvement. The second value is the parameter estimate for the binary aspect of volunteering (volunteering probability = volunteering $0-1$ ), which are odds ratios (OR), instead of $\beta$ 's. Odds ratio estimates between 0 and 1 represent an increase in the chance of having performed volunteering in the past year, and estimates above 1 represent a decrease in the chance of having performed volunteering in the past year. $\mathrm{ns}=p>0.1 ;{ }^{*}{ }^{*} p<0.1 ;{ }^{*} p<0.05 ;{ }^{* *} p<0.01$.

of personally relevant identity contexts were related to being more likely to volunteer and to more volunteering involvement. Yet, adolescents' identity integration was not related to how likely they were to volunteer and was negatively related to their volunteering involvement. Lastly, except for an indirect effect of moral understanding on adolescents' volunteering involvement (indirect $\mathrm{B}=-.08, p<.01$ ), no indirect effects of adolescents' morality were found on volunteering.

\section{Age differences}

A multi-group analysis with age as grouping variable revealed a better model fit for the model in which parameters were freely estimated than for the model in which parameters were constrained to be equal for both age groups (Satorra-Bentler corrected $\Delta \mathrm{X}^{2}(27)=71.42, p<0.01$ ). Statistically significant age differences in estimates are presented in Table 2 . We found age differences for the association between identity and volunteering. First of all, we found that the negative association between identity integration and volunteering involvement applied to younger but not older adolescents. Consequently, the indirect effect of moral understanding on volunteering via identity integration, was only significant for younger adolescents ( $\mathrm{B}=-0.11, p<0.01)$. No differences were found for identity integration and the probability to volunteer. Next to that, we found that a larger number of personally relevant identity contexts was associated with more volunteering involvement for younger adolescents and with being more likely to volunteering among older adolescents.

\section{Gender differences}

A multi-group analysis with gender as grouping variable revealed a better model fit for the model in which parameters were freely estimated than for the model in which parameters were constrained to be equal for both groups (Satorra-Bentler corrected $\left.\Delta \mathrm{X}^{2}(32)=70.91, p<0.01\right)$. Statistically significant gender differences in path estimates are presented in Table 2 . No

Table 2

Age and gender differences between the paths of the process model.

\begin{tabular}{|c|c|c|c|c|c|c|c|}
\hline & $\mathrm{B}(\mathrm{OR})$ & SE & $\beta$ & $\mathrm{B}(\mathrm{OR})$ & SE & $ß$ & pdiff \\
\hline & \multicolumn{7}{|l|}{ Age } \\
\hline & \multicolumn{3}{|l|}{ Young } & \multicolumn{3}{|l|}{ Old } & \multirow[b]{2}{*}{-} \\
\hline Moral referral - Identity integration & 0 & 0.02 & -0.02 & 0 & 0.02 & -0.01 & \\
\hline Identity integration - Volunteering 0-1 & $0.06(1.06)$ & -0.16 & 0.01 & $-0.16(0.85)$ & 0.56 & -0.02 & - \\
\hline Identity integration - Volunteer involvement & $-1.44 * *$ & 0.23 & -0.90 & -0.52 & 0.50 & -1.03 & $<0.01$ \\
\hline Identity contexts - Volunteering $0-1$ & $-0.03(0.97)$ & 0.10 & -0.02 & $-0.25^{*}(0.78)$ & 0.11 & -0.15 & $<0.05$ \\
\hline \multirow[t]{3}{*}{ Identity contexts - Volunteer involvement } & $0.20 *$ & 0.10 & 0.55 & 0.02 & 0.07 & 0.18 & $<0.05$ \\
\hline & \multicolumn{7}{|l|}{ Gender } \\
\hline & \multicolumn{3}{|l|}{ Boys } & \multicolumn{3}{|l|}{ Girls } & \\
\hline Moral referral - Identity integration & 0.02 & 0.02 & 0.07 & -0.03 & 0.02 & -0.12 & $<0.01$ \\
\hline Identity integration - Volunteering $0-1$ & 0.69 (1.99) & 0.50 & 0.10 & $-0.88(.41)$ & 0.59 & -0.11 & $<0.01$ \\
\hline Identity integration - Volunteer involvement & $-1.54 * *$ & 0.27 & -0.97 & -0.62 & 0.45 & -0.82 & $<0.01$ \\
\hline Identity contexts - Volunteering $0-1$ & $-0.14(0.87)$ & 0.10 & -0.09 & $-0.14(0.87)$ & 0.11 & -0.08 & - \\
\hline Identity contexts - Volunteer involvement & 0.11 & 0.07 & 0.34 & 0.11 & 0.09 & 0.66 & - \\
\hline
\end{tabular}

Note. Only the paths that showed age or gender differences are presented $(p<.05)$. Young = adolescents of $12-15$ years old; Old $=$ adolescents of $16-19$ years old. For the logistic regression part of the model (paths to the probability to volunteer = volunteering 0-1), B's are logits. These logits are inverted to odds ratios (OR), which are presented between brackets. Odds ratio's between 0 and 1 represent an increase in the chance of having performed volunteering in the past year, and estimates above 1 represent a decrease in the chance of having performed volunteering in the past year.

$*=p<.05 ; * *=p<.01 ;$ diff = statistical significance of the age and gender differences. 
differences were found between boys and girls, except for the relation between moral referral and identity integration (which were both non-significant relations), and for the relation between identity integration and volunteering involvement. A gender difference appeared in the relation between identity integration and the probability they had volunteered, though this relationship did not reach statistical significance for either boys $(p=.17)$ or girls $(p=0.14)$. Next to that we found a stronger, negative association between identity integration and volunteering involvement for boys than for girls (respectively, $\mathrm{B}=-1.54, p<.01 ; \mathrm{B}=-.62, p=.17$ ). Consequently, the indirect effect of moral understanding on volunteering via identity integration, was only significant for boys and not for girls $(\mathrm{B}=-0.13, p<0.01)$.

\section{Discussion}

In this study we examined the process by which various aspects of morality and identity are related to volunteering. As expected, we found that adolescents' moral reasoning was positively related to their general moral thought, which, in turn, was related to a further developed identity. For the relation between adolescents' identity and volunteering, clearest effects were found when differentiating between adolescent gender and age groups.

The relationship between adolescents' morality and identity

We found that a higher level of moral reasoning was positively associated with the cognitive elements of adolescents' general moral thought: It was related to a better understanding for actual, real life moral issues (moral understanding) and to being more able to think about the collective, moral responsibility for these issues (moral referral; Derryberry \& Thoma; 2005; Narvaez et al., 1999; Pitt \& Thoma, 2005; Rest, Thoma et al., 1999).

In turn, two of the three elements of general moral thought were related to adolescents' identity development. First of all, a further developed moral understanding was related to more solid identity integration (cf. Erikson, 1968; Jennings, 1996; van Hoof \& Raaijmakers, 2003). This suggests that having a better understanding of moral rights issues, which apply to all people, can provide adolescents with an overarching perspective or rules that can help to structure their personally relevant contextsspecific identities in an integrated whole. Future research could examine whether this overarching perspective is more moral (cf. Hofer, 1999; Jennings, 1996; Yates \& Youniss, 1996) or rather cognitive in nature (cf. Helwig, 1998; van Hoof \& Raaijmakers, 2003). Moral referral, on the other hand, was not related to adolescents' identity integration. It could be that, as adolescents have a limited amount of political rights and obligations (e.g., hardly any adolescent in our study had the right to vote in national or regional elections), governmental or public responsibility is no important guiding principle for their identity development yet (cf. Torney-Purta \& Amadeo, 2003; van Hoof \& Raaijmakers, 2002). Alternatively, the lesser importance of collective moral responsibility to adolescents' identity may be specific to Dutch society or to European societies (e.g., compared to USA society; cf. Torney-Purta, 2002; Torney-Purta \& Amadeo, 2003).

The motivational element of general moral thought, moral commitment, was positively related to the number of adolescents' identity contexts (cf. van Hoof \& Raaijmakers, 2002). This suggests that when adolescents feel more committed to a broader societal, moral perspective, they are also more likely to feel at home in a broader range of these societal contexts (i.e. a broadening of the identity horizon; e.g., van Hoof \& Raaijmakers, 2002).

\section{The relationship between adolescents' identity and volunteering}

Some indication was also found for a relation between adolescents' identity development and volunteering behaviour. First, when adolescents extended the number of their identity contexts, they tended be more likely to volunteer and, when they volunteered, they tended to perform volunteering activities more frequently (i.e. more volunteering involvement).

Second, adolescents' identity integration predicted their volunteering involvement but not how likely they were to volunteer. What initially seemed even more surprising was that adolescents' identity integration was not positively but negatively related to their volunteering involvement, which means that there was less cohesion between adolescents' context-specific identities when they volunteered more often.

Lastly, all findings on the relation between identity and volunteering became clearer when age and gender differences were considered, which will be discussed in the section on the moderation effects of age and gender on our process model.

\section{The relationship between adolescents' age and our process model}

We found that with age, adolescents developed a higher level of moral reasoning (cf. Eisenberg et al., 2005; e.g., Rest, 1979) and adolescents were more likely to volunteer (e.g., Metz \& Youniss, 2003). However, when they did volunteer, they were not more involved in volunteering activities than younger adolescents (e.g., Cheung, 2006). This suggests that although age plays a role in starting volunteering work, other factors are important in predicting how often adolescents will perform volunteering activities. Next to that, we did not find any indirect effects of age on volunteering, which suggests that our process model does not mediate this (linear) relation. Rather, our model could be age specific, as an indirect effect of moral reasoning on volunteering involvement was found for younger but not older adolescents. 
Moderation effects of age and gender differences on our process model

As mentioned before, the relations within our model became clearer when gender and age differences were considered. We found that age and gender differences were mainly present in the relation between adolescents' identity development and volunteering.

\section{Age differences}

Age differences show that the negative relation between adolescents' identity integration and volunteering involvement only applied to younger adolescents. Next to that we found that for younger adolescents, a higher number of personally relevant identity contexts was related to being more involved in volunteering activities (and not to being more likely to volunteer), whereas for older adolescents we found that a higher number of these identity contexts was related to being more likely to volunteer (and not to how involved they were when they volunteered). An additional finding was that, for younger adolescents, the relation between their level of moral reasoning and volunteering was mediated by their moral understanding and by their identity integration.

Overall these findings suggest that younger and older adolescents differ on how the broadening of their identity horizon is related to their volunteering behaviour: Whereas older adolescents start new activities when they broaden their identity horizon, this does not mean they will also (immediately) invest a lot of time and energy in these new activities. Possibly this may be due to older adolescents' former experiences on what consequences a large investment in a new activity or identity context can have on themselves, such as on their well-being (lower identity integration due to fragmentation of one's context-specific identities has shown to be negatively related to adolescents' well-being; van Hoof \& Raaijmakers, 2002). Younger adolescents, on the other hand, may lack this experience. Therefore, the enthusiasm often associated with new experiences and environments may make them invest more time in these new contexts and activities, such as volunteering, when they broaden their identity horizon. This may also explain why younger but not older adolescents' identity integration is negatively related to their volunteering involvement: It could be that whereas older adolescents do not experience a negative effect of being more involved in volunteering, the lack of experience in younger adolescents may cause that a larger time investment in volunteering leads to an imbalance in the integration of all personally relevant context-specific identities. For example, because a large investment in one context (e.g., volunteering) might also alter the content and relative importance of other identity contexts. In turn, this could negatively affect the cohesion between all personally relevant context-specific identities (e.g., van Hoof, 1997).

Alternatively or additionally, it could be the case that younger adolescents' identity integration is negatively related to their volunteering involvement, because for this group of adolescents more than for older adolescents, volunteering is a matter of identity exploration. This means that new identity contexts and activities adolescents encounter, such as volunteering, may become part of who they are, but are still relatively instable (i.e. not central to their identity; e.g., they can stop doing these activities or stop finding them personally relevant; cf. Hofer, 1999; i.e. Klimstra, Hale, Raaijmakers, Branje, \& Meeus, 2010) and therefore not yet integrated into their identity. This explanation suggests that not only assessing adolescents' personally relevant context-specific identities, but also assessing the extent to which these identities are personally relevant (how central these identities are to them), could be important and could provide a valuable addition in explaining the relation between identity and volunteering.

Lastly, due to the cross-sectional nature of our study, these explanations should be considered with some caution. To be able to make any strong inferences on the direction or causality of the age-specific relation between identity and volunteering, future longitudinal research is required.

\section{Gender differences}

Gender differences show that the negative relation between adolescents' identity integration and volunteering involvement mainly applied to boys. We also found that for boys, the relation between adolescents' moral understanding and volunteering was partly mediated by their identity integration.

Similar arguments proposed to explain age differences for the relation between identity and volunteering may apply to explain these gender differences: Perhaps boys experience volunteering more often as something to explore than girls (cf. Klimstra et al., 2010). First, this may be because volunteering may already be more part of girls' than of boys' identity. Former research has shown that girls volunteer more often in the company of friends and seek peer-approval by volunteering, in which case the volunteering behaviour could become part of who they are among their friends and peers. In contrast, boys seek out their own volunteering opportunities more often, in which case volunteering may be considered as a new identity context or experience (cf. Sundeen \& Raskoff, 1995; Wuthnow, 1995). Second, it could be that the kind of volunteering activities girls perform are already more part of their identity than the volunteering activities boys perform. For example, women and girls are more likely to be involved in volunteering in which caring is an important element, such as community, welfare, and educational volunteering (e.g., visiting the elderly at nursing homes; Dolnicar \& Randle, 2007; Hofer, 1999; McLellan \& Youniss, 2003). This volunteering behaviour may be already part of girls' identity due to their genderstereotypic role as being caring individuals (cf. Hofer, 1999; Metzger \& Smetana, 2009; Walker, 2000, 2002; Wilson, 2000). In contrast boys, like men, could be more involved in activities within sporting or recreational organizations (cf. Dolnicar \& Randle, 2007). In this case, although sports or recreation may already be part of who they are, volunteering within these organisations may not already be an aspect of boys' identity (cf. Metzger \& Smetana, 2009). Consequently, it could also be the 
case that when volunteering eventually becomes part of boys' identity, their identity integration may suffer more from this volunteering involvement than girls' identity integration.

Strengths, limitations, and implications of our study

Because this study is one of the first to examine gender and age differences for the relation between adolescents' identity and volunteering, all of these explanations are tentative. As mentioned before, although our results suggest that volunteering and identity may mutually influence each other over time (Flanagan, Bowes, Jonsson, Csapo, \& Sheblanova, 1998; Youniss, McLellan et al., 1997), the correlational and cross-sectional design of our study ultimately does not allow conclusions about development or causal links within our process model. Therefore more studies with longitudinal and (quasi) experimental designs are needed to examine the interconnections of identity and volunteering, but also morality, identity, and volunteering, and their mutual relationship over time.

Second, our model focused on a selection of important intrapersonal characteristics to explain adolescents' volunteering. Future research could include additional person characteristics as predictors, such as personality (e.g., Atkins, Hart, \& Donnelly, 2005), but also additional aspects of volunteering that apply to both volunteers and non-volunteers, such as future volunteering motivations (Chapman \& Morley, 1999). In addition, it would also be interesting to extend our personoriented model with important environmental predictors, to examine the relative importance of internal in relation to external processes preceding adolescents' volunteering, and to examine the gender and age specific effects of these processes. For example, research has shown that being member of an organization (e.g., Atkins et al., 2005), service-learning at school, and (volunteering of) parents, siblings, and peers (e.g., Andolina, Jenkins, Zukin, \& Keeter, 2003; McLellan \& Youniss, 2003; Smetana \& Metzger, 2005) are important precursors of adolescents' volunteering.

One of the strengths of this study is that by using the CPBI (van Goethem, 2009) to measure volunteering, we were able to not only explain how likely adolescents were to volunteer, but also, when they did volunteer, how much adolescents were involved in volunteering activities. Next to that, previous research has shown that adolescents often have misconceptions of what is considered to be volunteering (Andolina, Keeter et al., 2003) and, because of that, often not recognize their activities as volunteering activities. We have tried to avoid this misconception in our instrument for volunteering (CPBI; van Goethem, 2009), by providing adolescents with a clear definition of volunteering and by presenting specific volunteering activities to the adolescents.

This study also moved beyond single-variable theories by incorporating various interdependent aspects of adolescents' morality and identity to explain their volunteering in a comprehensive person-focused process model. We found that adolescents' volunteering behaviour does not depend (only) on their moral reasoning. What is also important, is applying this moral reasoning to thinking about real life moral rights issues, and incorporating this thinking together with a sense of moral commitment into an extending identity horizon. For boys and younger adolescents, their identity integration is also an important meditational factor in explaining their volunteering.

This knowledge may provide extra tools to current initiatives in stimulating adolescent civic participation. It suggests that adolescents' volunteering may increase when their morality and identity development is stimulated. For example, lessons in high school service learning programs could focus more on stimulating students to become more aware of real life moral issues and to reflect on their own responsibility and role within these issues. In addition, our study shows that this process preceding volunteering may be different for boys and girls, and for younger and older adolescents. This could mean that current initiatives could be more effective in stimulating volunteering when attenuated to these gender-, and age-differences.

\section{References}

Andolina, M., Keeter, S., Zukin, C., \& Jenkins, K. (2003). A guide to the index of civic and political engagement. College Park, MD: The Center for Information \& Research on Civic Learning \& Engagement. Retrieved from. http://www.civicyouth.org/PopUps/IndexGuide.pdf.

Andolina, M. W., Jenkins, K., Zukin, C., \& Keeter, S. (2003). Habits from home, lessons from school: influences on youth civic engagement. PS: Political Science and Politics, 36(2), 275-280, Retrieved from. http://www.jstor.org/stable/3649322.

Atkins, R., Hart, D., \& Donnelly, T. M. (2005). The association of childhood personality type with volunteering during adolescence. Merrill-Palmer Quarterly, 51(2), 145-162, Retrieved from. http://www.merrillpalmerquarterly.com.

Bekkers, R., \& Boezeman, E. (2009). Giving of time: volunteering. In T. N. M. Schuyt, B. M. Gouwenberg, \& R. Bekkers (Eds.), Geven in Nederland 2009: giften, sponsoring, legaten en vrijwilligerswerk. [Giving in the Netherlands 2009: gifts, sponsoring, legacies and volunteering work] (pp. 88-101). Amsterdam: Reed Business.

Bennett, S. E. (2000). Generations X and Y: America's continuing problem. In S. Man, \& J. J. Patrick (Eds.), Education for civic engagement in democracy. Service learning and other promising practices. Washington, DC: Corporation for National Service.

Bergman, R. (2002). Why be moral? A conceptual model from developmental psychology. Human Development, 45, 104-124, Retrieved from. http:// contentkarger.com/ProdukteDB/produkte.asp?Aktion=JournalHome\&ProduktNr=224\%20249.

Blasi, A. (1983). Moral cognition and moral action: a theoretical perspective. Developmental Review, 3, 178-210, Retrieved from. http://old.library. georgetown.edu/newjour/d/msg02240.html.

Blasi, A. (1995). Moral understanding and the moral personality: the process of moralintegration. In W. M. Kurtines, \& J. L. Gewirtz (Eds.), Moral development: An introduction. Boston: Allyn \& Bacon.

Boom, J., \& Brugman, D. (2005). Measuring moral development in adolescents. In W. Van Haaften, T. Wren, \& A. Tellings (Eds.), Moral sensibilities and education III: The adolescent (pp. 87-112). Bemmel: Concorde Publishing House.

Boulware-Miller, K. (1985). Female circumcision: challenges to the practice as a human rights violation. Harvard Women's Law Journal, 8, 155-177, Retrieved from. http://www.law.harvard.edu/students/orgs/jlg/.

Carlo, G., \& Randall, B. A. (2002). The development of a measure of prosocial behaviors for late adolescents. Journal of Youth and Adolescence, 31(1), 31-44. doi:10.1023/A:1014033032440. 
Chapman, J. G., \& Morley, R. (1999). Collegiate service-learning: motives underlying volunteerism and satisfaction with volunteer service. Journal of Prevention E Intervention in the Community, 18(1), 19-33. doi:10.1300/J 005v18n01_03.

Cheung, C. (2006). Experiential learning strategies for promoting adolescents' voluntarism in Hong Kong. Child E Youth Care Forum, 35, 57-78. doi:10.1007/ s10566-005-9003-6.

Clary, E. G., Snyder, M., Ridge, R. D., Copeland, J., Stukas, A. A., Haugen, J., et al. (1998). Understanding and assessing the motivations of volunteers: a functional approach. Journal of Personality and Social Psychology, 74(6), 1516-1530, Retrieved from. http://www.apa.org/journals/psp/.

Colby, A., Kohlberg, L., Speicher, B., Hewer, A., Candee, D., Gibbs, J., et al. (1987). The measurement of moral judgmentIn Standard Issue Scoring Manual, vol. II. Cambridge: Cambridge University Press.

Coleman, S., \& Rowe, C. (2005). Remixing citizenship. Democracy and young people's use of the Internet. Retrieved from. http://www.carnegieuktrust.org.uk/ files/main/Remixing\%20Citizenship.pdf.

Cook, S. A. (2004). Learning to be full Canadian citizen: youth, elections, and ignorance. Canadian Issues Magazine1-6, September. Retrieved from. http:// www.magamall.com/client/Disticor/Magamall_V201_MainEngine.nsf/f653519e8f751393852571710069f3c3/0e723042a853282e85256f7900725c12! Open Document.

Côté, J. E., \& Levine, C. (2002). Identity formation, agency, and culture. A social psychological synthesis. Mahwah, NJ: Lawrence Erlbaum.

Derryberry, W. P., \& Thoma, S. J. (2005). Functional differences: comparing moral judgement developmental phases of consolidation and transition. Journal of Moral Education, 34(1), 89-106. doi:10.1080/03057240500049372.

Doise, W., Spini, D., Jesuino, J. C., Ng, S. H., \& Emler, N. (1994). Values and perceived conflicts in the social representations of human rights: feasibility of a crossnational study. Swiss Journal of Psychology, 53, 240-251, Retrieved from. http://www.verlag-hanshuber.com/zeitschriften/journal.php?abbrev=sjp.

Dolnicar, S., \& Randle, M. (2007). What motivates which volunteers? Psychographic heterogeneity among volunteers in Australia. Voluntas, 18, 135-155. doi: $10.1007 / \mathrm{s} 11266-007-9037$.

Dornbusch, S. M., Herman, M. R., \& Morley, J. A. (1996). Domains of adolescent achievement. In G. R. Adams, R. Montemayor, \& T. P. Gullotta (Eds.), Psychosocial development during adolescence (pp. 181-231). Thousand Oaks, CA: Sage.

Eisenberg, N. (1982). Introduction: the relationship between prosocial behavior and moral reasoning. In N. Eisenberg (Ed.), The development of prosocial behavior (pp. 15). New York: Academic Press.

Eisenberg, N., Carlo, G., Murphy, B., \& Van Court, P. (1995). Prosocial development in late adolescence: a longitudinal study. Child Development, 66, 11791197, Retrieved from. http://www.wiley.com/bw/journal.asp?ref=0009-3920.

Eisenberg, N., Cumberland, A., Guthrie, I. K., Murphy, B. C., \& Shepard, S. A. (2005). Age changes in prosocial responding and moral reasoning in adolescence and early adulthood. Journal of Research on Adolescence, 15(3), 235-260. http://www.wiley.com/bw/journal.asp?ref=1050-8392.

Erikson, E. H. (1968). Identity: Youth and crisis. New York: Norton.

Fabes, R. A., Carlo, G., Kupanoff, K., \& Laible, D. (1999). Early adolescence and prosocial/moral behaviour I: the role of individual processes. Journal of Early Adolescence, 19(5), 5-16. doi:10.1177/0272431699019001001.

Flanagan, C. A., Bowes, J. M., Jonsson, B., Csapo, B., \& Sheblanova, E. (1998). Ties that bind: correlates of adolescents' civic commitments in seven countries. Journal of Social Issues, 54, 457-475, Retrieved from. http://www.wiley.com/bw/journal.asp?ref=0022-4537.

Flanagan, C., Levine, P., \& Settersten, R. A., Jr. (2009). Civic engagement and the changing transition to adulthood. College Park, MD: The Center for Information \& Research on Civic Learning \& Engagement. Retrieved from. http://www.hhs.oregonstate.

Gaskin, K., \& Smith, J. D. (1997). A new civic Europe? Study of the extent and role of volunteering. London: Volunteer Centre UK.

van Goethem, A. A. J. (2009, July). The role of moral development, identity, family characteristics, and personality in the civic prosocial behavior of adolescents. A proposal. Poster presented at the 35th annual conference of the Association for Moral Education. Utrecht.

Grube, J. A., \& Piliavin, J. A. (2000). Role identity, organizational experiences, and volunteering performance. Personality and Social Psychology Bulletin, 26, 1108-1119, doi: 101177/01461672002611007.

Hardy, S. A. (2006). Identity, reasoning, and emotion: an empirical comparison of three sources of moral motivation. Motivation and Emotion, 30, $207-215$. doi:10.1007/s11031-006-9034-9.

Harris, A., Wyn, J., \& Younes, S. (2010). Beyond apathetic or activist youth: 'ordinary' young people and contemporary forms of participation. Young, 18(1), 932. doi:10.1177/110330880901800103.

Helwig, C. (1998). Children's conceptions of fair government and freedom of speech. Child Development, 69, 518-531, Retrieved from. http://www.wiley. com/bw/journal.asp?ref $=0009-3920$.

Higgins-D’Alessandro, A. (2008). Moral education and citizenship education at pre-university schools. In F. Oser, \& W. Veugelers (Eds.), Getting involved. Global citizenship development and sources of moral values. Rotterdam: Sense Publishers.

Hofer, M. (1999). Community service and social cognitive development in German adolescents. In M. Yates, \& J. Youniss (Eds.), Roots of civic identity. International perspectives on community service and activism in youth. Cambridge: Cambridge University Press.

van Hoof, A. (1997). Identity formation in adolescence: Structural integration and guiding influences (Unpublished doctoral dissertation). Utrecht University, The Netherlands.

van Hoof, A. (1999). The identity status field re-reviewed: an update of unresolved and neglected issues with a view on some alternative approaches. Developmental Review, 19, 497-556. doi:10.1006/drev.1999.0484.

van Hoof, A., \& Raaijmakers, Q. A. W. (2002). The spatial integration of adolescent identity: its relation to age, education, and subjective well-being. Scandinavian Journal of Psychology, 43(3), 201-212. doi:10.1111/1467-9450.00288.

van Hoof, A., \& Raaijmakers, Q. A. W. (2003). The search for the structure of identity formation. Identity: An International Journal of Theory and Research, 3 , 271-289, Retrieved from. http://www.informaworld.com/smpp/title $\sim$ content=t775653653.

van Hoof, A., \& Raaijmakers, Q. A. W. (2010). The Children's Rights Evaluation Questionnaire (CREQ). Unpublished report. The Netherlands: Utrecht University.

Jennings, T. E. (1996). The developmental dialectic of international human-rights advocacy. Political Psychology, 17(1), 77-95, Retrieved from. http://www. wiley.com/bw/journal.asp?ref=0162-895X.

Karniol, R., Grosz, E., \& Schorr, I. (2003). Caring, gender role orientation, and volunteering. Sex Roles, 49(1/2), 11-19. http://www.springer.com/psychology/ personality+\%26+social+psychology/journal/11199.

Klimstra, T. A., Hale, W. W., III, Raaijmakers, Q. A. W., Branje, S. J. T., \& Meeus, W. H. J. (2010). Identity information in adolescence: change or stability? Journal of Youth Adolescence, 39, 150-162. doi:10.1007/s10964-009-9401-4.

Kohlberg, L. (1969). Stage and sequence: the cognitive-developmental approach to socialization. In D. A. Goslin (Ed.), Handbook of socialization theory and research (pp. 347-480). Chicago: Rand McNally.

Kohlberg, L., \& Candee, D. (1984). The relationship between moral judgment to moral actions. In L. Kohlberg (Ed.), Essays on moral development: The nature and validity of moral stages, Vol. 2 (pp. 498-581). San Francisco: Harper and Row.

Kroger, J. (1988). A longitudinal study of ego identity status interview domains. Journal of Adolescence, 11, 49-64, Retrieved from. http://www.elsevier.com/ wps/find/journaldescription.cws_home/622849/description/description.

Kroger, J. (1993). Ego identity: an overview. In J. Kroger (Ed.), Discussions on ego identity (pp. 1-20). Hillsdale, NJ: Erlbaum.

Lambert, D. (1992). Zero-inflated poisson regression, with an application to defects in manufacturing. Technometrics, 34, 1-14, Retrieved from. http://www. amstat.org/publications/tech.cfm.

Lansdown, G. (1995). Children's rights. In B. Mayall (Ed.), Children's childhoods observed and experienced (pp. 33-44). London: The Falmer Press.

Lies, J., \& Bock, T. (2008). What does it take to give? Moral identity, moral reasoning and religiosity as predictors of civic engagement. In F. K. Oser, \& W. Veugelers (Eds.), Getting involved. Global citizenship development and sources of moral values. Rotterdam: Sense Publishers.

Little, T. D., Cunningham, W. A., Shahar, G., \& Widaman, K. F. (2002). To parcel or not to parcel: exploring the question, weighting the merits. Structural Equation Modelling: A Multidisciplinary Journal, 9, 151-173. doi:10.1207/S15328007SEM0902_1. 
Low, N., Butt, S., Ellis Paine, A., \& Davis Smith, J. (2007). Helping out: A national study of volunteering and charitable giving. London: Cabinet Office.

Matsuba, M. K., Hart, D., \& Atkins, R. (2007). Psychological and social-structural influences on commitment to volunteering. Journal of Research in Personality, 41, 889-907. doi:10.1016/j.jrp.2006.11.001

McLellan, J. A., \& Youniss, J. (2003). Two systems of youth service: determinants of voluntary and required youth community service. Journal of Youth and Adolescence, 32, 47-58, Retrieved from. http://www.springer.com/psychology/child+\&+school+psychology/journal/10964.

Metz, E., \& Youniss, J. (2003). A demonstration that school-based required service does not deter-but-heightens-volunteerism. PS: Political Science and Politics, 36(2), 281-286, Retrieved from. http://www.jstor.org/action/showPublication?journalCode=pspolisciepoli.

Metzger, A., \& Smetana, J. G. (2009). Adolescent civic and political engagement: associations between domain-specific judgments and behavior. Child Development, 80, 433-441, Retrieved from. http://www.wiley.com/bw/journal.asp?ref=0009-3920.

MOVISIE. (2011). Jongeren participatie. Trends en cijfers. Available at http://www.movisie.nl/116871/def/home/jongerenparticipatie/trends_en_feiten/ Accessed 05.07.11.

Muthén, L. K., \& Muthén, B. O. (1998-2010). Mplus. User's guide (Sixth Edition).. Los Angeles, CA: Muthén \& Muthén. Retrieved from. http://www.statmodel. com/download/usersguide/Mplus\%20Users\%20Guide\%20v6.pdf.

Narvaez, D., Getz, I., Rest, J. R., \& Thoma, S. J. (1999). Individual moral judgment and cultural ideologies. Developmental Psychology, 35(2), 478-488, Retrieved from. http://www.apa.org/pubs/journals/dev/.

Nucci, L. P. (1996). Morality and personal freedom. In E. S. Reed, E. Turiel, \& T. Brown (Eds.), Values and knowledge (pp. 41-60). Mahwah, NJ: Erlbaum.

Omoto, A. M., \& Snyder, M. (2002). Considerations of community: the context and process of volunteerism. American Behavioral Scientist, 45, 846-867. doi: $10.1177 / 0002764202045005007$.

Pitt, D. W., \& Thoma, S. J. (2005). Moral judgment, self-understanding, and moral actions: the role of multiple constructs. Merrill-Palmer Quarterly, 51(1), 67-92. doi:10.1353/mpq.2005.0005.

Proulx, T., \& Chandler, M. J. (2009). Jekyll and Hyde and me: age-graded differences in conceptions of self-unity. Human Development, 52, 261-286. doi:10. $1159 / 000233259$

Raaijmakers, Q. A. W., \& van Hoof, A. (2006). Does moral reasoning represent sociomoral structure or political ideology? A further exploration of the relations between moral reasoning, political attitudes, consistency of moral thought, and the evaluation of human rights in Dutch young adults. Social Behavior and Personality, 34, 617-638, Retrieved from. http://www.sbp-journal.com/.

Rest, J. R. (1979). Revised manual for the Defining issues test. Unpublished manuscript. Minneapolis: University of Minnesota.

Rest, J. R., Narvaez, D., Bebeau, M. J., \& Thoma, S. J. (1999). Postconventional moral thinking. A neo-kohlbergian approach. London: Lawrence Erlbaum Associates.

Rest, J. R., Narvaez, D., Thoma, S. J., \& Bebeau, M. J. (1999). DIT2: devising and testing a revised instrument of moral judgment. Journal of Educational Psychology, 91(4), 644-659, Retrieved from. http://www.apa.org/pubs/journals/edu/.

Rest, J., Thoma, S., \& Edwards, L. (1997). Designing and validating a measure of moral judgment: stage preference and stage consistency approaches. Journal of Educational Psychology, 89, 5-28, Retrieved from. http://www.apa.org/pubs/journals/edu/.

Rest, J. R., Thoma, S. J., Narvaez, D., \& Bebeau, M. J. (1997). Alchemy and beyond: indexing the defining issues test. Journal of Educational Psychology, 89, 498-507, Retrieved from. http://www.apa.org/pubs/journals/edu/.

Satorra, A., \& Bentler, P. M. (2001). A scaled difference chi-square test statistic for moment structure analysis. Psychometrika, 66, 507-514, Retrieved from. http://www.psychometrika.org/.

Smetana, J. G., \& Metzger, A. (2005). Family and religious antecedents of civic involvement in middle class African American late adolescents. Journal of Research on Adolescence, 15(3), 325-352. doi:10.1111/j.1532-7795.2005.00099.x.

Sundeen, R., \& Raskoff, S. (1995). Teenage volunteers and their values. Nonprofit Voluntary Sector Quarterly, 24, 337-357, Retrieved from. http://nvs.sagepub. $\mathrm{com} /$.

Thoma, S. J. (2002). An overview of the Minnesota approach to research in moral development. Journal of Moral Education, 31(3), 225-246. doi:10.1080/ 0305724022000008098

Torney-Purta, J. (1991). Schema theory and cognitive psychology: implications for social studies. Theory and Research in Social Education, 19, 189-210, Retrieved from. http://www.socialstudies.org/cufa/trse.

Torney-Purta, J. (2002). Patterns in the civic knowledge, engagement, and attitudes of European adolescents: the IEA civic education study. European Journal of Education, 37(2), 129-141, Retrieved from. http://www.blackwellpublishing.com/journal.asp?ref=0141-8211.

Torney-Purta, J., \& Amadeo, J. (2003). A cross-national analysis of political and civic involvement among adolescents. PS: Political Science and Politics, 36(2), 269-274, Retrieved from. http://www.jstor.org/action/showPublication?journalCode=pspolisciepoli.

Walker, T. (2000). The service/politics split: rethinking service to teach political engagement. Political Science E Politics, 33, 646-649, Retrieved from. http:// www.jstor.org/action/showPublication?journalCode $=$ pspolisciepoli.

Walker, T. (2002). Service as a pathway to political participation: what research tells us. Applied Developmental Science, 6, 183-188. doi:10.1207| S1532480XADS 0604_4.

Walker, L. J. (2004). Progress and prospects in the psychology of moral development. Merrill-Palmer Quarterly, 50(4), 546-557, Retrieved from. http://www. merrillpalmerquarterly.com/.

Wilson, J. (2000). Volunteering. Annual Review of Sociology, 26, 215-240, Retrieved from. http://www.annualreviews.org/loi/soc.

Wuthnow, R. (1995). Learning to care. New York: Oxford University Press.

Yates, M., \& Youniss, J. (1998). Community service and political identity development in adolescence. Journal of Social Issues, 54, 495-512, Retrieved from. http://www.wiley.com/bw/journal.asp?ref=0022-4537.

Yates, M., \& Youniss, J. (1996). Community service and political-moral identity development in adolescence. Journal of Research on Adolescence, 6, 271-284, Retrieved from. http://www.blackwellpublishing.com/journal.asp?ref=105\%200-8392.

Yau, J., \& Smetana, J. (2003). Conceptions of moral, social-conventional, and personal events among Chinese preschoolers in Hong Kong. Child Development, 74, 647-658, Retrieved from. http://www.wiley.com/bw/journal.asp?ref=0009-3920.

Youniss, J., McLellan, J. A., \& Yates, M. (1997). What we know about engendering civic identity. American Behavioral Scientist, 40, 620-631. doi:10.1177/00027 64297040005008 .

Youniss, J., \& Yates, M. (1999). Youth service and moral-civic identity: a case for everyday morality. Educational Psychology Review, 11, 361-376, Retrieved from. http://www.springerlink.com/content/104855/.

Youniss, J., Yates, M., \& Sue, Y. (1997). Social integration: community service and marijuana use in high school seniors. Journal of Adolescent Research, 12, 245-262, Retrieved from. http://jar.sagepub.com/.

Zukin, C., Keeter, S., Andolina, M., Jenkins, K., \& Delli Carpini, M. X. (2006). A new engagement? Political participation, civic life, and the changing American citizen. New York: Oxford University Press. 